\title{
Glacier meltwater chemistry at two sub-polar glaciers in West Greenland
}

\author{
Jørn-Ole Andreasen
}

As part of a glacier hydrological study electrical conductivity of meltwaters from two subpolar glaciers was investigated. The dissolved load of a melt stream reflects the mixing, in varying proportions through time, of waters with different chemical characteristics from different environments (Collins, 1977). Conductivity, a surrogate measure of the concentration of total dissolved solids, was used as an indicator of the nature of subglacial and englacial hydrochemical environments and of different meltwater routings through the glaciers.

The investigation was carried out at Qamanârssûp sermia, an outlet glacier from the Inland Ice, in 1981 and at Kitdlerssuaq, on an outlet glacier from a local ice cap, in 1982 and 1983 (fig. 45). All conductivity values are reported at the measuring temperature, i.e. $0-2^{\circ} \mathrm{C}$ for glacier meltwater.

\section{Qamanârssûp sermia}

At Qamanârssûp sermia discrete measurements of conductivity and water level were made in a marginal melt stream in 1981 . The stream emerged at approximately $850 \mathrm{~m}$ above sea level from where it ran $1.5 \mathrm{~km}$ along the southern margin until it entered a minor icedammed lake. The stream was running partly underneath the glacier, through dead ice and outside ice-covered areas. Measurements were made as the stream emerged from dead ice.

Fig. 45. Sketch map of West Greenland showing location of the glaciers Qamanârssûp sermia and Kitdlerssuaq. Dashed line on the Inland Ice denotes boundary of the area covered by the GGU basin and glacier inventory.

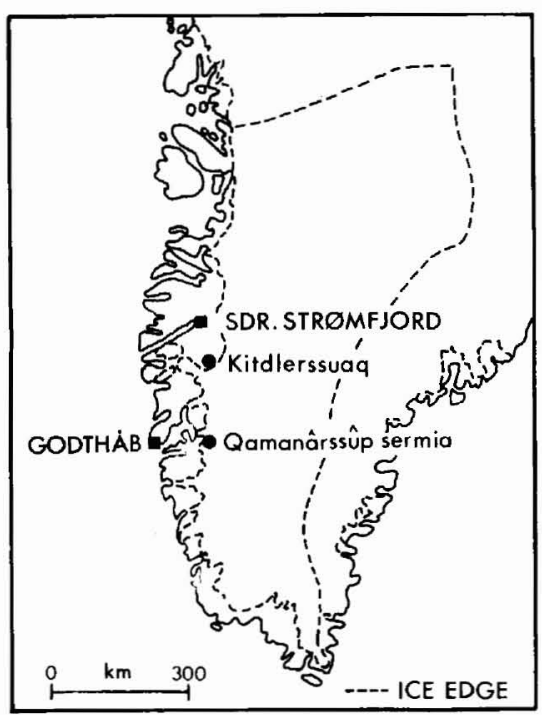




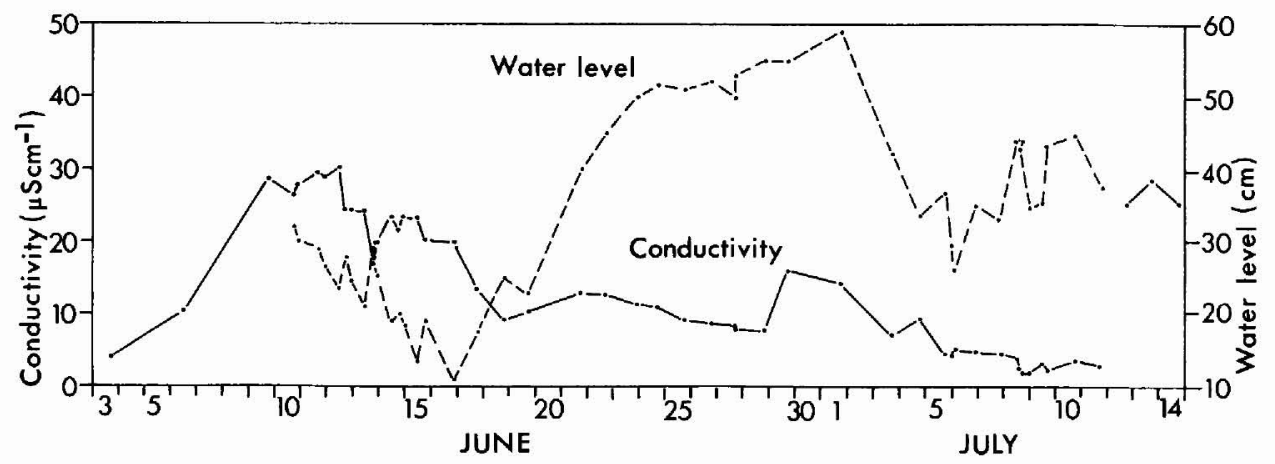

Fig. 46. Conductivity and water level in the marginal meltwater stream, Qamanârssûp sermia 1981.

At the beginning of June 1981 conductivity was low, but then it rose to high values around $30 \mu \mathrm{Scm}^{-1}$ (fig. 46). In the period 9th to 16th June conductivity values between 20 and 30 $\mu \mathrm{Scm}^{-1}$ were obtained, and although both conductivity and water level were generally falling in the period, they varied inversely on a shorter time scale. Following increased ablation on the glacier surface, water level rose, but after an initial fall conductivity variations seemed to be almost independent of water level fluctuations (e.g. 4-11th July), conductivity simply fell from approximately $13 \mu \mathrm{Scm}^{-1}$ to $3 \mu \mathrm{Scm}^{-1}$. Between 12 th and 13 th July the marginal stream drained underneath the glacier; the only water left in the former stream bed was a small amount of water from local ice melt.

Discrete conductivity measurements of different waters in the area (lakes, bog waters, small creeks etc.) all gave readings between $5 \mu \mathrm{Scm}^{-1}$ and $12 \mu \mathrm{Scm}^{-1}$. Two outlets from Qamanârssûp sermia showed low conductivity values; one stream left the glacier draining south at $980 \mathrm{~m}$ above sea level (up to $8 \mu \mathrm{Scm}^{-1}$ ), the other left the glacier draining north at $750 \mathrm{~m}$ above sea level (one reading, $2 \mu \mathrm{Scm}^{-1}$ ). No measurements were made in the main outlet ( $50 \mathrm{~m}$ above sea level), but conductivity in the main outlet from the glacier immediately to the north of Qamanârssûp sermia (at $400 \mathrm{~m}$ ) was low (up to $6 \mu \mathrm{Scm}^{-1}$ ). High conductivity values measured in two ponds in ice-cored moraine $\left(38\right.$ and $57 \mu \mathrm{Scm}^{-1}$ ) may be due to concentration of solutes because of evaporation.

\section{Kitdlerssuaq}

Discrete conductivity measurements were made in the main meltwater outlet in front of the glacier at Kitdlerssuaq (glacier inventory no. 1DG16166) from 2nd to 14th July 1982, and from 14th July to 7th September a continuous record of conductivity was obtained (fig. 47).

At least half of the discharge in the main meltwater stream in front of the glacier comes from a marginal melt stream on the northern side of the glacier. The marginal melt stream (approximately $1 \mathrm{~km}$ long) ran in newly cut channels in old moraine deposits.

The discrete measurements showed markedly decreasing conductivity at the beginning of July. From then conductivity varied inversely with water level and ablation, but even when ablation totally ceased conductivity only increased to approximately $3.2 \mu \mathrm{Scm}^{-1}$. However, it should be noted that conductivity in a nearby subglacial outlet was somewhat higher, up to $6.5 \mu \mathrm{Scm}^{-1}$. 

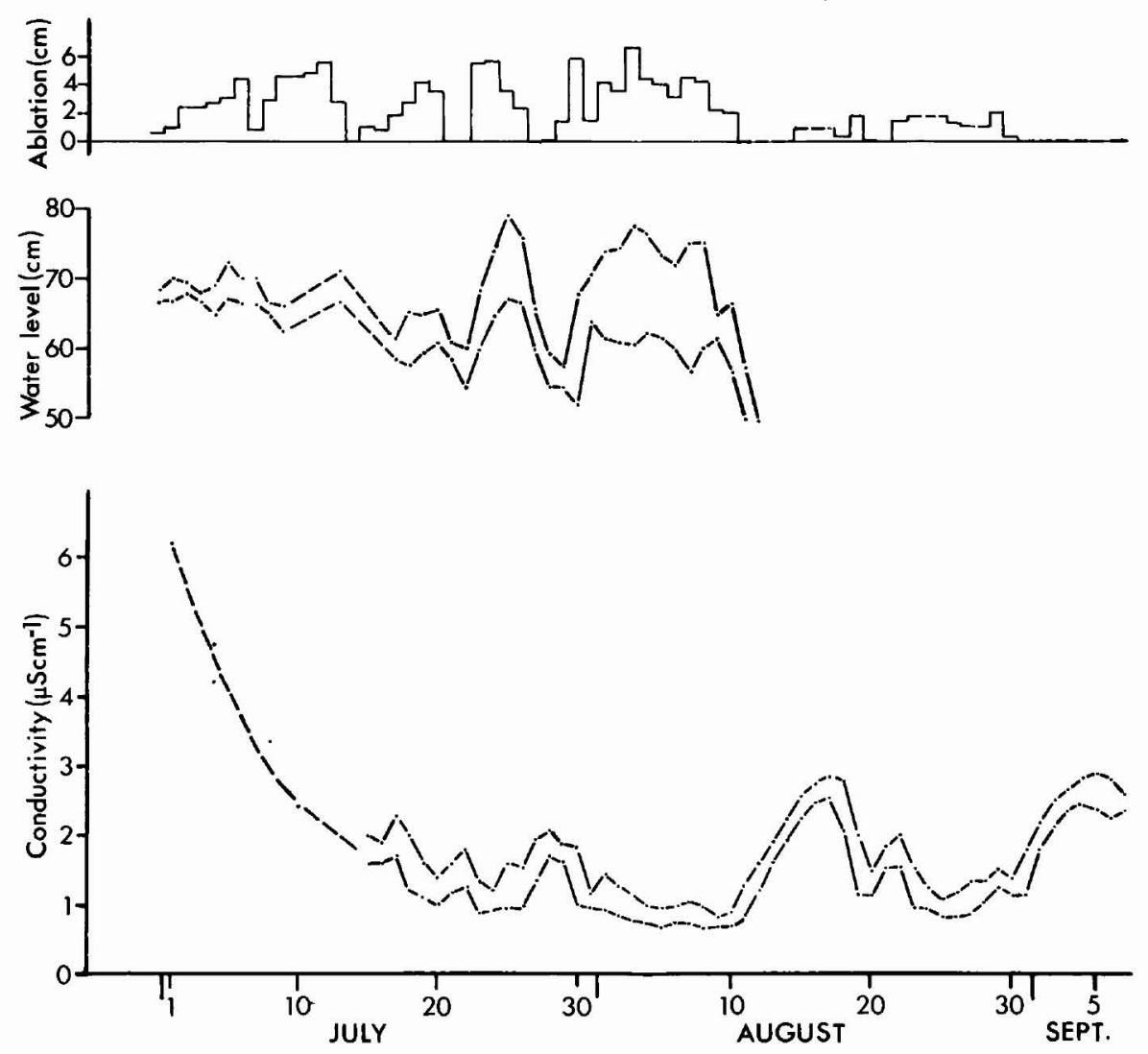

Fig. 47. Ice ablation and daily minimum and maximum conductivity and water level, Kitdlerssuaq 1982.

\section{Discussion}

Inverse variations between stream discharge (water level) and concentrations of dissolved materials (conductivity) in glacier meltwater streams have for a long time been explained as a result of dilution of solute-rich waters (subglacial water or groundwater) by relatively pure waters derived directly from snow and ice melt (Rainwater \& Guy, 1961; Church, 1974). In fact Collins (1979) used this concept in a quantitative separation of total flow into water routed through the subglacial system and water routed through the englacial system.

On a short time scale (one day) dilution by relatively pure water derived directly from the daily ablation of ice may explain why the maximum water level coincides with the minimum conductivity in the period 9-16th June at Qamanârssûp sermia. But in the same period both water and conductivity were generally falling, and the marked water level fluctuations in July were not reflected in the conductivity. Moreover conductivity was low compared with the conductivity in meltwater streams reported in the literature.

Almost the same trend was recognized at Kitdlerssuaq. Only initial and final conductivity were lower than at Qamanârssûp sermia and conductivity and water level also varied inversely at low conductivity values. These results suggest that a reservoir of stored water 
with a relatively high content of dissolved matter is drained at the beginning of the melt season. Thereafter only small amounts of dissolved matter are available.

In an Alpine environment Lemmens (1975) found a very rapid enrichment in dissolved solids of meltwater running only some tens of metres on moraine. Considering that meltwaters at Qamanârssûp sermia and at Kitdlerssuaq were running through ice-cored moraine, or in newly cut channels in old moraine deposits, the low conductivity in the streams is surprising. This may be due to the poor chemical weathering of morainic material in the arctic environment.

It is also notable that conductivity in the seepage from the ice-cored moraine at Qamanârssûp sermia (12-13th July) was the same as conductivity in the melt stream at the beginning of June. These results indicate that climate and time of contact between water and sediment are important factors in determining the conductivity of glacier meltwater.

In relation to hydropower the application of conductivity as an indicator of meltwater routings through glaciers is complicated. The possible relations between conductivity and climate, bedrock lithology and contact time between water and sediment need further investigation.

\section{References}

Church, M. 1974: On the quality of some waters on Baffin Island, Northwest Territories. Can. J. Earth Sci. 11, 1676-1688.

Collins, D. N. 1977: Hydrology of an Alpine glacier as indicated by the chemical composition of meltwater. Z. Gletscherk. Glazialgeol. 13, 219-238.

Collins, D. N. 1979: Quantitative determination of the subglacial hydrology of two Alpine glaciers. $J$. Glaciol. 23, 347-361.

Lemmens, M. 1975: De l'exportation du sodium et du potassium par les eaux de fusion d'un glacier alpin en région calcaire. Catena 2, 203-214.

Rainwater, F. H. \& Guy, H. P. 1961: Some observations on the hydrochemistry and sedimentation of the Chamberlin Glacier area, Alaska. Prof. Pap. U.S. geol. Surv. 414-C, 14 pp.

Geologisk Institut, Aarhus Universitet, Langelandsgade, bygn. 521, 8000 Arhus $C$ Denmark. 